\title{
Wpływ kształcenia podyplomowego na rozwój kompetencji zawodowych pielęgniarek opieki długoterminowej
}

\section{The influence of post-graduate education on the development of professional skills in long-term nursing}

\author{
KATARZYNA ROGOWSKA', MONIKA RYCHLEWSKA ${ }^{2,3}$ \\ ${ }^{1}$ Centrum Medyczne Grupa Zdrowie, Kraszewo-Czubaki \\ 2Instytut Nauk o Zdrowiu, Państwowa Uczelnia Zawodowa we Włocławku \\ 3 Wojewódzki Szpital Specjalistyczny we Włocławku im. bł. ks. J. Popiełuszki, Oddział \\ Chirurgii Ogólnej
}

DOI: http://dx.doi.org/10.21784/IwP.2019.015

ISSN: 2451-1846

\section{Streszczenie:}

Wstęp. Poziom opieki świadczonej pacjentom przebywającym w placówkach opieki długoterminowej jest niezmiernie istotny. Zmiany organizmu spowodowane procesami chorobowymi oraz na ogół cięższym i powikłanym ich przebiegiem, powodują, że wykonywanie usług pielęgnacyjnych wymaga ściśle określonego postępowania zgodnego z najlepszym aktualnie dostępnym dowodem klinicznym.

Cel. Celem pracy była ocena wpływu kształcenia podyplomowego pielęgniarek opieki długoterminowej na wzrost ich kompetencji zawodowych w zakresie profilaktyki i pielęgnowania odleżyn.

Materiał i metody. W pracy posłużono się metodą sondażu diagnostycznego. Narzędziem badawczym, które pomogło zgromadzić dane, był autorski kwestionariusz ankiety. Badania przeprowadzono w Zakładzie Opiekuńczo-Leczniczym w Kraszewo-Czubaki w okresie styczeń - luty 2018 r. i została nimi objęta grupa 50 pielęgniarek tam pracujących.

Wyniki. Analiza statystyczna wykazała istotną zależność pomiędzy uczestnictwem w kursach dotyczących profilaktyki i pielęgnacji odleżyn 
przez pielęgniarki, a tym jakie metody profilaktyki przeciwodleżynowej stosują. Nie zaobserwowano istotnej statystycznie zależności pomiędzy wykształceniem i stażem pracy pielęgniarek a znajomością: skal dotyczących oceny ryzyka rozwoju odleżyn, czynników ryzyka i punktacji wg skali Norton, klasyfikacji wg Thorrance'a, zasadami pielęgnacji ran przewlekłych

Wnioski. Zastosowanie w praktyce wiedzy zdobytej przez pielęgniarki podczas kształcenia podyplomowego przyczynia się nie tylko do polepszania ich usług, ale poprawia też jakość życia pacjentów.

Słowa kluczowe: odleżyny, profilaktyka, wiedza , pielęgniarka

\begin{abstract}
:
Introduction. The level of quality of care for patients in long-term care facilities is of vital importance. Changes in the body caused by disease or complicated course of disease lead to the fact that nursing care provided must be in accordance with the best available clinical proof.

Aim. The aim of this study was to evaluate the influence of post-graduate education on the development of professional skills in long-term nursing and the activities of bedsore prevention.

Material and methods. The diagnostic survey was used and the main research tool applied, which helped to collect the data needed, was our own survey questionnaire. The study was carried out in Nursing Home in Kraszewo-Czubaki over the period January -February 2018. The survey research covered a group of 50 nurses.
\end{abstract}

Results. Statistical analysis showed significant relationship between the participation in training courses devoted to preassure sores prevention and the methods chosen by nurses. There was no statistically significant relationship among education, professional experience of nurses and the knowledge of the assesment of risk for the development of preassure sores, risk factors and the score in Norton Scale, classification by Thorrance, preassure sores care.

Conclusions. To application of the knowledge acquired in post-graduate education in practice contributes to improvement of nursing care but also improves patients' quality of life.

Keywords: preassure sores, prevention, knowledge, nurse 


\section{Wstęp}

Odleżyny to jeden z problemów pielęgnacyjnych pacjentów przebywających $\mathrm{w}$ placówkach opieki długoterminowej. Mimo rozwoju medycyny i coraz większych możliwości terapeutycznych, skala tego zjawiska jest bardzo duża. Istnieje wiele elementów, które odgrywają znaczącą rolę $\mathrm{w}$ procesie tworzenia odleżyn. Ich współistnienie pięciokrotnie zwiększa ryzyko wystąpienia rany.

Wśród uwarunkowań powstania odleżyn wyróżnia się czynniki wewnętrzne oraz zewnętrzne.

Do czynników wewnętrznych (ustrojowych) zalicza się:

- wiek - proces starzenia znacznie zwiększa predyspozycje do rozwoju odleżyn; wiąże się to ze zmianami, które zachodzą w obrębie skóry oraz z ograniczeniem aktywności ruchowej;

- płeć - skóra kobiet jest na ogół cieńsza i delikatniejsza, w związku z czym płeć żeńska jest bardziej zagrożona rozwojem patologicznych zmian na skórze;

- masa ciała - nadwaga powoduje wzrost ucisku w miejscach, gdzie tkanka kostna jest okryta cienką warstwą tkanki podskórnej; niedowaga czy też brak odpowiedniej ilości tkanki tłuszczowej wywołują zwiększenie nacisku powierzchniowego na skórę;

- temperatura ciała - obniżona ciepłota ciała $\left(<36,6^{\circ} \mathrm{C}\right)$ doprowadza do obkurczenia naczyń krwionośnych i w związku z tym zaburzenia perfuzji na poziomie tkankowym; gorączka z kolei zwiększa potliwość i wilgotność skóry oraz wzmaga metabolizm;

- kondycja/rodzaje skóry - najbardziej podatna na uszkodzenia jest skóra osób w podeszłym wieku; spowodowane jest to zmniejszeniem tkanki podskórnej, obniżeniem elastyczności skóry i wrażliwości na bodźce bólowe;

- aktywność/uruchomienie - najbardziej niekorzystne jest unieruchomienie pacjenta $\mathrm{w}$ jednej pozycji, gdy masa ciała jest skupiona na małej powierzchni, co prowadzi do zwiększenia nacisku; 
- czynność zwieraczy odbytu i cewki moczowej - wilgotne środowisko oraz kwaśny odczyn moczu i kału powodują zmianę pH skóry, jej rozmiękanie, niejednokrotnie doprowadzając do maceracji naskórka oraz zmniejszenia odporności skóry na urazy[1];

- apetyt/odżywianie - ogólne wyniszczenie, niedożywienie, niedobór witaminy $\mathrm{C}, \mathrm{B}_{12}$, $\mathrm{Zn}$ i Fe oraz dieta uboga w białko znacząco wpływają na rozwój odleżyn[2]; u osób w podeszłym wieku bardzo duży wpływ na stan odżywienia ma występowanie dysfagii, trudności w gryzieniu oraz przełykaniu[3];

- gospodarka wodno-elektrolitowa - zarówno odwodnienie organizmu, jak i uogólnione obrzęki mają wpływ na kondycję skóry, zaburzając przepływ tkankowy;

- stan psychiczny - pacjenci z zaburzeniami psychicznymi nie przestrzegają zaleceń odnośnie pielęgnacji skóry;

- niewydolność układu neurologicznego, zaburzenia świadomości chorzy po udarze mózgu, uszkodzeniu rdzenia kręgowego, pacjenci wapatii nie odczuwają dyskomfortu bólowego spowodowanego długotrwałym uciskiem, co prowadzi do nasilenia się zmian;

- niewydolność układu krążenia - obniżone parametry Hb i RBC, niskie ciśnienie krwi, uszkodzenie naczyń obwodowych w przebiegu cukrzycy, miażdżycy zmniejsza elastyczność naczyń krwionośnych; - niewydolność układu oddechowego - przewlekłe stany zapalne oskrzeli i płuc, rozedma, gruźlica, astma, słabsza wydolność mięśni oddechowych, duszność powodują niedotlenienie tkanek organizmu; - zabiegi usprawniające pracę układu kostno-mięśniowego - pacjenci po zabiegach ortopedycznych kręgosłupa, po wszczepieniu endoprotezy, z założonym gipsem, stabilizatorem zewnętrznym są w grupie ryzyka powstania odleżyn;

- choroby współistniejące, które zwiększają możliwość wystąpienia odleżyn to: miażdżyca, cukrzyca, otyłość, anemia, choroby nowotworowe, stwardnienie rozsiane, a także alkoholizm i nikotynizm [1]. 
Czynniki zewnętrzne mające wpływ na powstawanie odleżyn to:

- długotrwały ucisk - spowodowany niemożliwością lub brakiem zmiany pozycji,

- tarcie - może towarzyszyć nieprawidłowej zmianie pozycji ciała, czynnościom higienicznym[4],

- temperatura otoczenia - niska - może spowodować wychłodzenie organizmu, obkurczenie naczyń krwionośnych a następnie osłabienie przepływu tkankowego; zbyt wysoka natomiast wywołuje wzmożoną potliwość;

- poziom opieki - czynniki obniżające jakość świadczonych usług na rzecz pacjenta to m.in.: niedostateczny poziom wiedzy, brak standardów, złe nawyki, niedostatki kadrowe, zła organizacja pracy, brak narzędzi pomiaru stopnia ryzyka, trudny dostęp do szkoleń;

- bielizna pościelowa - najlepiej, gdy jest wykonana z miękkich i suchych materiałów, powinna być dokładnie naciągnięta i umocowana, żeby nie powstawały zagniecenia; należy również unikać stosowania foliowych podkładów, gdyż mogą wywołać odparzenia[1];

- złe warunki ekonomiczne - brak odpowiedniego sprzętu p/odleżynowego, opatrunków i środków higienicznych [5];

- leki - środki p/bólowe, psychotropowe, uspokajające i sterydy wpływają na ograniczenie reakcji chorego na bodźce [6].

Do powstania odleżyn może dojść w dowolnej części ciała. Jednak ponad $70 \%$ ran tworzy się w obrębie dolnej połowy ciała i w zależności od pozycji, jaką przyjmuje pacjent, powstają one w okolicy: kości krzyżowej (ok. 40\%), krętarzy (ok. 10\%), guzów piętowych (ok. 10\%), guzów kulszowych (ok. 5\%) i kostek bocznych goleni (ok. 5\%)[7].

W zależności od przyjętego kryterium wyróżnia się kilka podziałów odleżyn. Ze względu na czas wymagany do wyleczenia dzieli się je na: 
- odleżyny zwykłe, gdzie nie dochodzi do zaburzeń ukrwienia, i które goją się w okresie kilku tygodni;

- odleżyny miażdżycowe, w przypadku których czas gojenia wydłuża się do kilkunastu tygodni ze względu na zaburzenia ukrwienia;

- odleżyny terminalne występujące u ludzi umierających, które nie ulegają wygojeniu.

Istnieje także kilka podziałów stopnia zaawansowania odleżyn ze względu na ich wygląd, głębokość lub wielkość. Są to m.in.: skala Guttmana, skala Thorrance'a, skala Enisa i Sarmiento.

Ocena ryzyka i rozpoznanie pacjenta zagrożonego wystąpieniem odleżyn opiera się na dokładnym oraz starannym prowadzeniu dokumentacji pielęgniarskiej $\mathrm{z}$ wykorzystaniem dostępnych skal [8]. Pionierską skalą w tej dziedzinie jest punktowa skala oceny ryzyka rozwoju odleżyn wg Doreen Norton. Uwzględnia się w niej 5 elementów: stan fizykalny, stan świadomości, aktywności, samodzielności podczas zmiany pozycji ciała, funkcję zwieraczy odbytu i cewki moczowej. Każdy czynnik jest osobno analizowany w skali czterostopniowej (1-4 pkt.). Maksymalnie chory może otrzymać 20 pkt. Wartość graniczną stanowi 14 pkt. i oznacza zagrożenie powstaniem odleżyn [9].

Każdy pacjent $\mathrm{w}$ momencie przyjęcia na oddział podlega szczegółowej ocenie pod kątem zagrożenia wystąpieniem odleżyn. Jeśli w chwili przyjęcia stwierdza się odleżyny, to oceniana jest ich lokalizacja, stadium, rozległość uszkodzenia, ilość i rodzaj wysięku, obecność przetok i rozległość tkanek zmacerowanych lub martwiczych. Po tym etapie ustala się indywidualny program opieki. Pacjenci bez odleżyn podlegają zaś szczegółowo opisanej procedurze profilaktycznej. Uzyskany materiał stanowi element dokumentacji medycznej chorego[5].

Podczas wszelkich zabiegów pielęgnacyjnych oraz przy przemieszczaniu podopiecznego, należy zadbać o jego bezpieczeństwo, a także zwrócić szczególną uwagę, aby nie uszkodzić jego delikatnej skóry. W związku z tym niezbędne jest stosowanie 
sprzętu pomocniczego, np. podnośników. Dzięki tym przedmiotom ogranicza się ryzyko mikrourazów naskórka, a także wysiłek personelu i ból pacjenta.

Kolejny element prewencji odleżyn to stosowanie materacy przeciwodleżynowych różnych klas. Rodzaj materaca powinno się dobierać indywidualnie, w zależności od stanu chorego i poziomu ryzyka rozwoju odleżyn, czy też stopnia występującej już odleżyny. Materace stosuje się $\mathrm{w}$ celu zmniejszenia ciśnienia międzypowierzchniowego.

Duże znaczenie w działaniach przeciwodleżynowych ma ocena stanu skóry oraz zabiegi pielęgnacyjne zapobiegające jej uszkodzeniu. Bardzo ważne są codzienne czynności higieniczne. Skóra powinna pozostawać czysta i sucha. Należy ją myć ciepłą wodą $\mathrm{z}$ delikatnymi środkami oczyszczającymi. Zaleca się mydło o pH 5,5 nie zawierające perfum, mydło szare lub dziecięce. Można stosować preparaty zawierające lanolinę. Po każdym myciu skórę powinno się delikatnie osuszyć, zwłaszcza w fałdach.

Dodatkowo $w$ ramach działań profilaktycznych można stosować opatrunki hydrokoloidowe. Zarówno te standardowe, jak i cienkie oraz folię poliuretanową lub opatrunki silikonowe takie jak: Vellaform, Silflex, które głównie chronią przed działaniem sił tnących i tarcia.

Ważnym elementem profilaktyki przeciwodleżynowej jest ocena oraz postępowanie $\mathrm{w}$ przypadku upośledzenia funkcji zwieraczy, czyli nietrzymania moczu i stolca. Ocena rodzaju dysfunkcji zwieraczy powinna obejmować przyczyny, które ją powodują, np. objawy uboczne stosowanych leków, zakażenie układu moczowego[10]. Istotne jest także, aby zastosowane metody nie eliminowały wysiłków podejmowanych w celu odzyskania przez pacjenta sprawności zwieraczy [6].

Kolejnym aspektem zapobiegania odleżynom jest dieta i uzupełnianie niedoborów pokarmowych. 
Rodzina powinna uczestniczyć $\mathrm{w}$ działaniach $\mathrm{z}$ zakresu profilaktyki p/odleżynowej.

U pacjentów, u których pomimo stosowania różnych zabiegów profilaktycznych dochodzi do rozwoju odleżyn lub odleżyny powstały wcześniej, konieczne jest wdrożenie nowoczesnego leczenia. Jest to proces długotrwały i wymagający skojarzenia różnych wzajemnie uzupełniających się działań. Mimo istniejącego podziału na leczenie ogólne i miejscowe, to zawsze leczenie powinno być interdyscyplinarne, uwzględniające wszystkie aspekty patofizjologii trudno gojącej się rany. Tak więc, w działaniach terapeutycznych nadal obowiązuje kontynuacja czynności profilaktycznych, które mogą wymagać modyfikacji i zintensyfikowania[11].

\section{Cel}

Celem pracy była ocena wpływu kształcenia podyplomowego pielęgniarek opieki długoterminowej na wzrost ich kompetencji zawodowych w zakresie profilaktyki i pielęgnowania odleżyn.

\section{Materiał i metody}

Badaniami została objęta grupa 50 pielęgniarek opieki długoterminowej pracujących w Zakładzie Opiekuńczo-Leczniczym w Kraszewo-Czubaki. Miały one charakter anonimowy i dobrowolny. Uzyskane wyniki badań poddano analizie statystycznej testem $\chi^{2}$ dla prób niezależnych. Przyjęto 5\% ryzyka błędu wnioskowania. Wartość prawdopodobieństwa $\mathrm{p}<0,05$ uznano za statystycznie istotną.

Analiza badań została przedstawiona $\mathrm{w}$ postaci tabel i wykresów. Kwestionariusz ankiety własnego autorstwa użyto jako narzędzie do pozyskania wyników badań, które zostały poddane interpretacji $\mathrm{w}$ kierunku wyznaczonych hipotez oraz problemów badawczych. 


\section{Wyniki}

Staż pracy pielęgniarek uczestniczących $\mathrm{w}$ badaniu był zróżnicowany: 26\% badanych to pielęgniarki pracujące 31-40 lat; $28 \%$ ankietowanych posiadało staż pracy 21-30 lat; $22 \%$ respondentów pracuje $11-20$ lat. Natomiast $24 \%$ badanych osób zadeklarowało, iż pracuje w zawodzie 1-10 lat. Staż pracy badanych prezentuje rycina $\mathrm{nr} 1$.

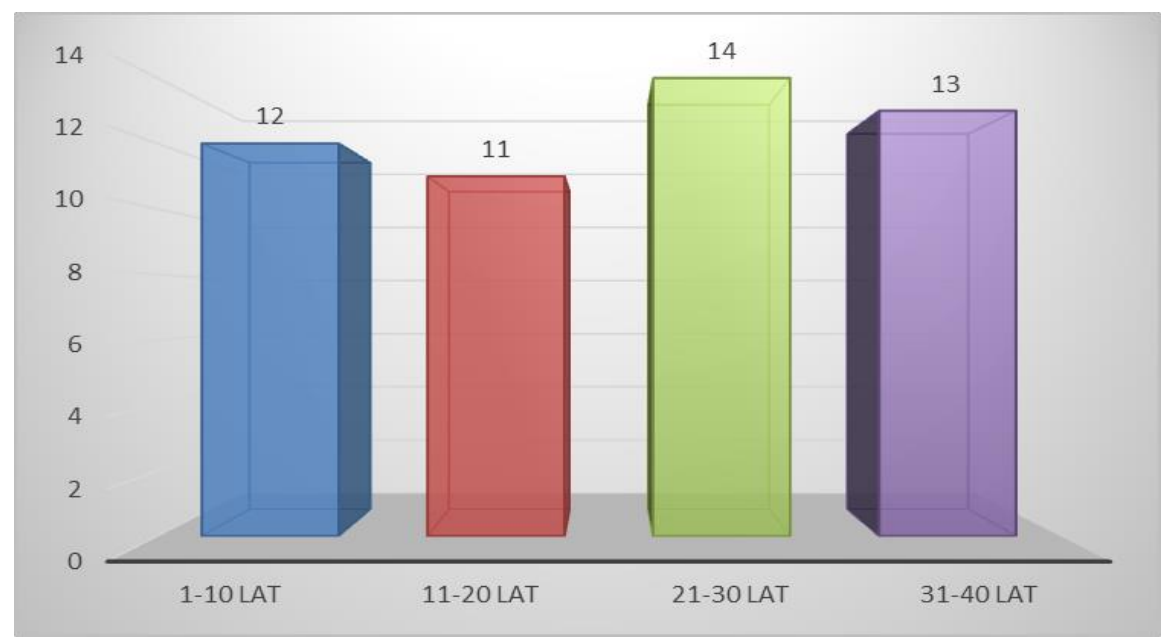

Ryc.1. Staż pracy zawodowej badanych.

Większość respondentów (44\% badanej grupy) to absolwenci liceum, bądź studium medycznego. Tytuł licencjata pielęgniarstwa posiadało $32 \%$ ankietowanych a $24 \%$ to magistrzy pielęgniarstwa. Wykształcenie badanych prezentuje rycina 2 . 


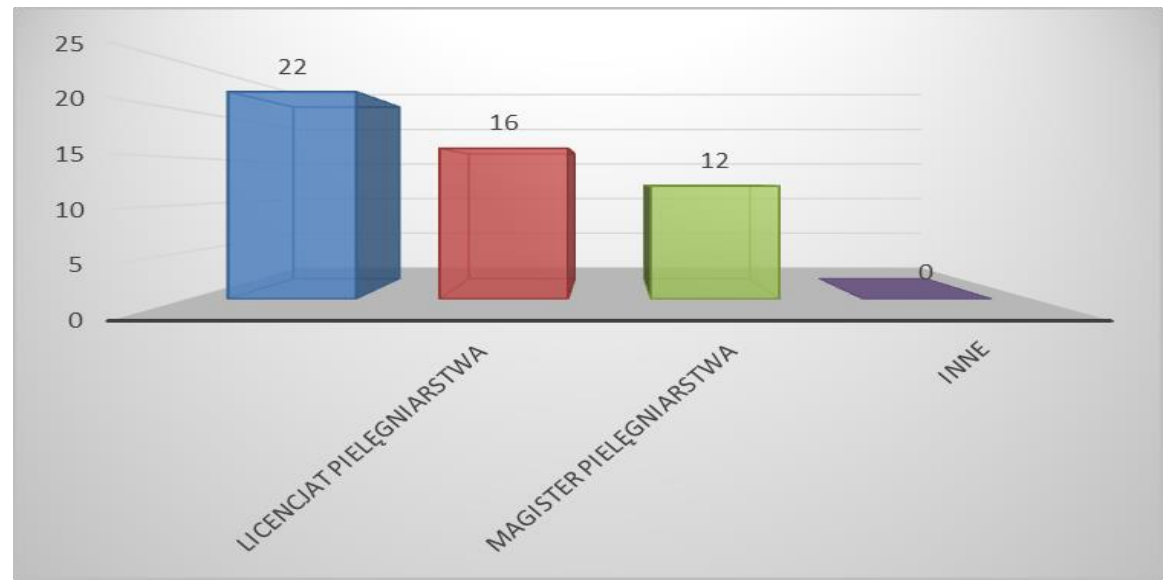

Ryc.2. Wykształcenie badanych.

Pielęgniarki deklarowały uczestnictwo w kształceniu podyplomowym: kursach, szkoleniach i konferencjach zawodowych. Udział w ponad pięciu formach kształcenia deklarowało $22 \%$ respondentów; 6\% badanych $\mathrm{w}$ ogóle nie uczestniczyło $\mathrm{w}$ takich działaniach. Z kolei 56\% pielęgniarek, biorących udział $\mathrm{w}$ formach kształcenia podyplomowego, uczestniczyło także w kursach dotyczących profilaktyki i pielęgnacji odleżyn. Rycina 3 i 4 prezentuje uczestnictwo respondentów w rożnych formach doskonalenia zawodowego. 


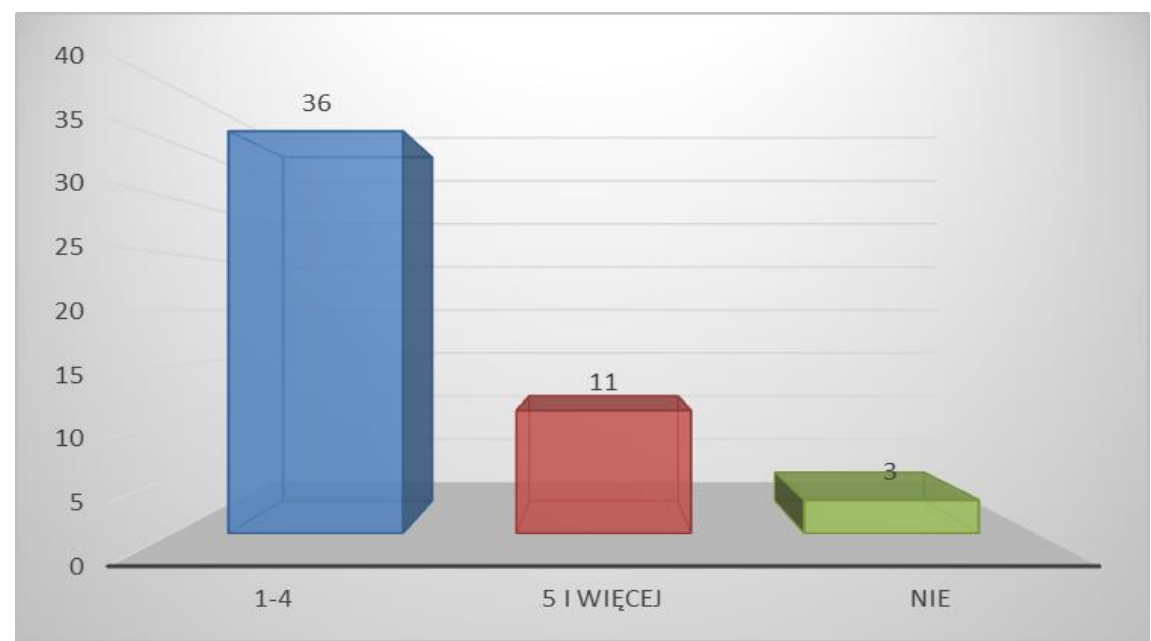

Ryc. 3. Uczestnictwo badanych w kursach, szkoleniach, konferencjach zawodowych.

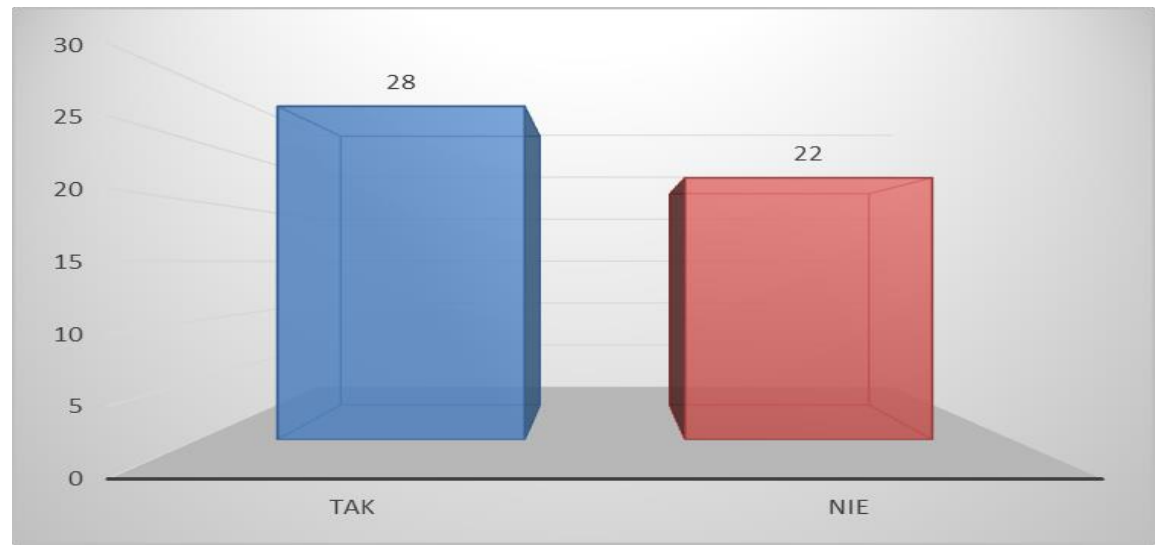

Ryc. 4. Uczestnictwo badanych w kursach dotyczących profilaktyki i pielęgnacji odleżyn.

Analiza statystyczna wykazała istotną zależność pomiędzy uczestnictwem $\mathrm{w}$ kursach dotyczących profilaktyki i pielęgnacji odleżyn przez ankietowanych, a tym jakie metody profilaktyki przeciwodleżynowej stosują. Ponad $11 \%$ ankietowanych, którzy 
uczestniczyli w kursach przyznaje, iż edukuje pacjenta oraz jego rodzinę. Więcej niż 10\% pielęgniarek deklaruje także, że wykonuje profilaktyczne opatrunki. Z kolei ponad 16\% ankietowanych, które nie uczestniczyły $\mathrm{w}$ kursach przyznaje, że stosuje $\mathrm{w}$ profilaktyce przeciwodleżynowej sprzęt pomocniczy i różnego rodzaju udogodnienia. Ponad 15\% tej grupy zmienia pozycję ułożeniową chorego. Natomiast jedynie ok. $2 \%$ badanych wykonuje profilaktyczne opatrunki i ponad 3\% edukuje pacjenta oraz jego rodzinę.

Rycina 5 prezentuje samoocenę poziom wiedzy i kompetencji zawodowych badanych.

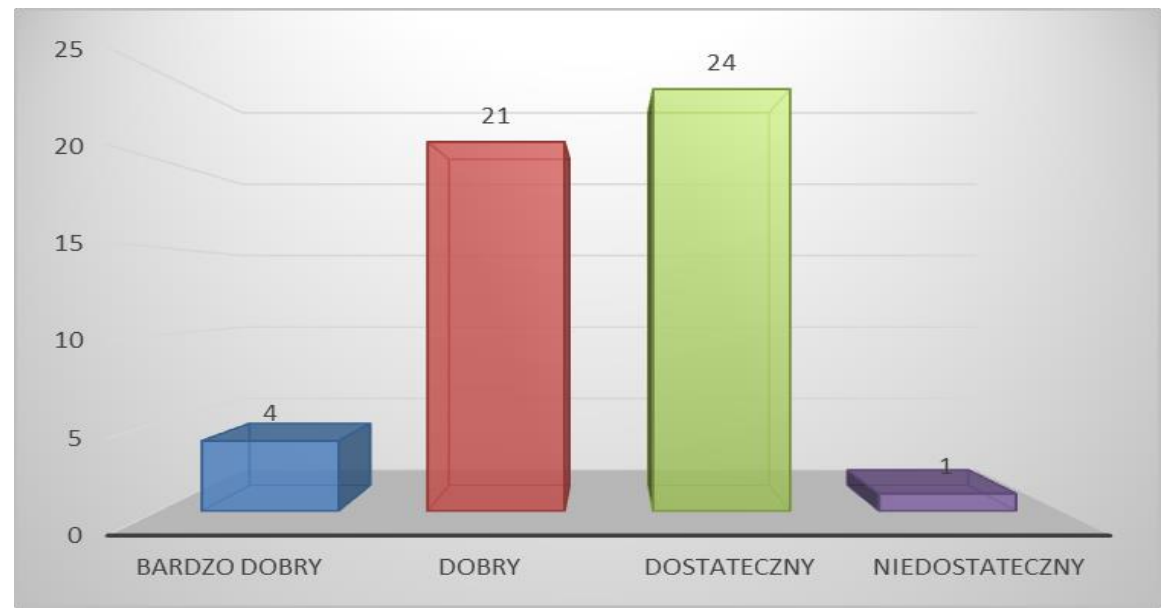

Ryc. 5. Ocena badanych nt. poziomu własnej wiedzy i kompetencji zawodowych.

Większość pielęgniarek ocenia poziom własnej wiedzy i kompetencji zawodowych jako dostateczny - 48\% osób i dobry $42 \%$ osób. Tylko $8 \%$ ankietowanych wskazało na poziom bardzo dobry a $2 \%$ osób na niedostateczny.

W grupie badanej przeważał średni poziom wiedzy na temat profilaktyki p/odleżynowej $(46 \%$ respondentów $)$ Natomiast 
$36 \%$ pielęgniarek określiło swoją wiedzę na poziomie bardzo dobrym a 18\%- na poziomie niskim. Rycina 6 prezentuje samoocenę poziomu wiedzy badanych nt. profilaktyki p/odleżynowej.

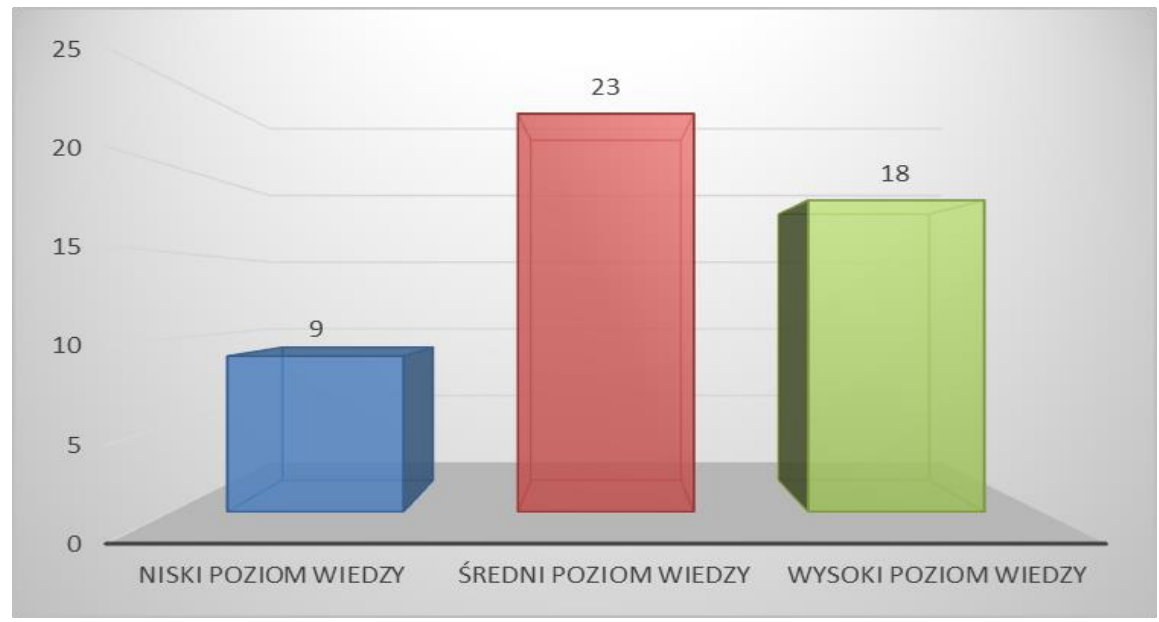

Ryc. 6. Poziom wiedzy pielęgniarek $w$ zakresie zagadnień związanych z profilaktyką p/odleżynową.

Nie zaobserwowano istotnej statystycznie zależności pomiędzy wykształceniem i stażem pracy pielęgniarek a ich wiedzą w zakresie znajomości: skal dotyczących oceny ryzyka rozwoju odleżyn, czynników ryzyka wg skali Norton, objawów infekcji w ranie, antyseptyków zalecanych do oczyszczenia rany przewlekłej, etapów postępowania $\mathrm{w}$ przebiegu zakażenia rany, rodzajów opatrunków stosowanych w zaopatrywaniu odleżyn.

Analiza statystyczna wykazała jedynie zależność pomiędzy wykształceniem ankietowanych a ich wiedzą nt. ilości dni koniecznych do pozostawiania na odleżynie błony poliuretanowej. Połowa absolwentów liceum lub studium medycznym uważa że powinny to być 3 dni. Natomiast ponad $83 \%$ magistrów pielęgniarstwa twierdzi, że to okres do $7 \mathrm{dni}$. 


\section{Dyskusja}

Badania własne wykazały istotną zależność pomiędzy uczestnictwem $\mathrm{w}$ kursach dotyczących profilaktyki i pielęgnacji odleżyn przez ankietowanych, a tym jakie metody profilaktyki przeciwodleżynowej stosują.

W opinii zdecydowanej większości pielęgniarek opieki długoterminowej posiadają one średnie lub wysokie kompetencje zawodowe i wiedze specjalistyczną.

W 2002 roku przeprowadzono badania wśród pielęgniarek pracujących w Klinice Neurologii, których celem było określenie wiedzy pielęgniarek w zakresie profilaktyki i pielęgnowania odleżyn, a także określenie czynników utrudniających opiekę nad pacjentami z odleżynami oraz poznanie opinii pielęgniarek na temat przyjętego standardu postępowania. Udział w szkoleniach wewnątrzoddziałowych dotyczących odleżyn zadeklarowało 95\% badanych. Wszystkie pielęgniarki natomiast uważają, że wiedza na temat odleżyn powinna być systematycznie uaktualniana w ramach szkoleń [12].

W wyniku analizy badań własnych nie zaobserwowano istotnej statystycznie zależności pomiędzy stażem pracy ankietowanych, a ich poziomem wiedzy $\mathrm{w}$ zakresie profilaktyki i pielęgnacji odleżyn. Nie wykazano również znaczącego wpływu stopnia wykształcenia na poziom wiedzy pielęgniarek w omawianym zakresie. Analiza statystyczna wykazała jedynie zależność pomiędzy wykształceniem ankietowanych, a ich wiedzą dotycząca okresu pozostawiania na odleżynie błony poliuretanowej.

Podobne wyniki uzyskano $\mathrm{w}$ badaniach przeprowadzonych w 2014 roku na grupie 100 pielęgniarek, które posiadały specjalistyczne kwalifikacje[13].

\section{Wnioski}

Na podstawie analizy wyników przeprowadzonych badań wysunięto następujące wnioski: 
1. Uczestnictwo $\mathrm{w}$ kursach dotyczących profilaktyki i pielęgnacji odleżyn ma znaczący wpływ na wzrost kompetencji pielęgniarek na to, jakie metody profilaktyki przeciwodleżynowej stosują w codziennej pracy zawodowej.

2. Staż pracy i wykształcenie pielęgniarek nie ma wpływu na poziom wiedzy pielęgniarek w zakresie profilaktyki i pielęgnacji odleżyn.

\section{Zalecenia dla praktyki pielęgniarskiej}

Systematyczny udział w zróżnicowanych formach kształcenia podyplomowego umożliwia pielęgniarkom wdrażanie dobrych praktyk w zakresie profilaktyki i pielęgnacji odleżyn u pacjentów.

\section{Bibliografia/Bibliography:}

1. Jakieła K., Krzemińska S., Borodzicz-Cedro A., Arendarczyk M. Czynniki wewnętrzne i zewnętrzne wpływające na powstawanie odleżyn u pacjentów leczonych na oddziale anestezjologii i intensywnej terapii. Pielęgniarstwo i Zdrowie Publiczne. 2014;(2):135-142.

2. Krupińska E. Ocena ryzyka powstania odleżyn przy użyciu dostępnych skal - opis przypadku. Problemy Pielęgniarstwa. 2012;(3):380-384.

3. Dullek M., Młynarska A. Ocena stanu odżywienia i ryzyka powstania odleżyn wśród pensjonariuszek zakładu opiekuńczo-leczniczego. Współczesne Pielęgniarstwo i Ochrona Zdrowia. 2016;(1):3-6.

4. Kiejda J., Jaracz K. Skuteczne zapobieganie odleżynom i ich leczenie przegląd dostępnych $\mathrm{w}$ Polsce metod pielęgnowania oraz leczenia. Zakażenia. 2007;7(4):96-101.

5. Ligas M., Wojtkiewicz W. Odleżynom można zapobiec. Ogólnopolski Przewodnik Medyczny. 2008(5):36-40.

6. Rauer K., Rauer J.: Etiologia, patogeneza i profilaktyka odleżyn. Pielęgniarstwo Polskie. 2007;1(23):41-47. 
7. Dzikowska M., Merklinger-Soma M., Gajda K. Analiza występowania odleżyn u pacjentów przebywających w szpitalu specjalistycznym o profilu zachowawczym. Probl. Pielęg. 2011;19(2):162-170.

8. Graczyk M., Bronszkiewicz E., Zgorzelak B.: Profilaktyka i leczenie odleżyn - ocena pacjentów przebywających na oddziale stacjonarnym Hospicjum im. bł. ks. J. Popiełuszki w Bydgoszczy w latach 2012-2013. Medycyna Paliatywna w Praktyce. 2014;8 (3):91-102.

9. Cierzniakowska K., Szewczyk M., Łabuńska A., Michalak S., Popow A. Jawień A. Ocena ryzyka rozwoju odleżyn na podstawie skali Doreen Norton. Leczenie Ran. 2011;8(1):7-13.

10. Butlewska B., Kurowska K. Odleżyny to poważny problem. Magazyn Pielęgniarki i Położnej. 2011;(3):8-9.

11. Krasowski G., Kruk M. Leczenie odleżyn i ran przewlekłych. Wydawnictwo Lekarskie PZWL. Warszawa 2008;24-43.

12.Ślusarz R., Beuth W., Książkiewicz B., Śniegocki M., Pawlas A. Wiedza pielęgniarek $\mathrm{z}$ oddziału neurologii na temat profilaktyki i pielęgnowania odleżyn - ocena przyjętego standardu. Annales Universitatis Mariae Curie-Skłodowska. 2003;319-324.

13. Bazaliński D., Fąfara A., Ząbek P., Kózka M. Profilaktyka i leczenie odleżyn w praktyce personelu pielęgniarskiego oddziałów neurologicznych w odniesieniu do wytycznych Polskiego Towarzystwa Leczenia Ran. Doniesienie wstępne. Leczenie Ran. 2015;179-186.

Otrzymano: 28.10.2019r.

Zaakceptowano: 14.11.2019r. 
